\title{
A Rainfall Intensity-Duration Threshold for Mass Movement in Badulla, Sri Lanka
}

\author{
E. N. C. Perera1, D. T. Jayawardana ${ }^{2}$, Pathmakumara Jayasinghe ${ }^{3}$ \\ ${ }^{1}$ Institute of Human Resource Advancement (IHRA), University of Colombo, Colombo, Sri Lanka \\ ${ }^{2}$ Faculty of Applied Science, Department of Forestry and Environmental Science, Sri Jayewardenepura Universities, Gangodawila, \\ Nugegoda, Sri Lanka \\ ${ }^{3}$ Landslides Research and Risk Management Division, National Building Research Organization, Colombo, Sri Lanka \\ Email: chinssu@gmail.com,daham@sci.sjp.ac.lk,jpathmak@gmail.com
}

How to cite this paper: Perera, E.N.C., Jayawardana, D.T. and Jayasinghe, P. (2017) A Rainfall Intensity-Duration Threshold for Mass Movement in Badulla, Sri Lanka. Journal of Geoscience and Environment Protection, 5, 135-152.

https://doi.org/10.4236/gep.2017.512010

Received: November 16, 2017

Accepted: December 22, 2017

Published: December 25, 2017

Copyright (C) 2017 by authors and Scientific Research Publishing Inc. This work is licensed under the Creative Commons Attribution International License (CC BY 4.0).

http://creativecommons.org/licenses/by/4.0/

\section{Open Access}

\begin{abstract}
Mass movement in Sri Lanka is mainly triggered by heavy rainfall. International literature is rich of works defining rainfall intensity-duration models to identify the rainfall threshold for various types of Mass movement. However, studies have not focused to establish a relationship between intensity and duration of rainfall in Sri Lanka. Therefore, this study focused to establish rainfall intensity-duration models to identify the rainfall threshold for mass movements in Badulla district in Sri Lanka, where forty four (44) rainfall events that resulted in same number of landslides during the last three decades were considered. Results indicate the rainfall threshold relationship fits to the log linear model of the exponential function, $I=\alpha \cdot D^{-\beta}$. The constructed I-D curve revealed that short duration $(<2 \mathrm{~h})$ and high-intensity $(>54 \mathrm{~mm} / \mathrm{h})$ in rainfall events can potentially trigger the landslide. However, long-duration $(>8 \mathrm{~h})$ and low-intensity $(<25 \mathrm{~mm} / \mathrm{h})$ in rainfall events may also trigger mass movements in Badulla. As per the results, most mass movements occur during northeast monsoons and inter-monsoons. In general, higher mean rainfall intensities trigger the debris flows, while long-duration rainfall events can trigger both landslides and debris flow. When compared to Sri Lankan mass movements triggering threshold intensities are fairly higher than the global threshold values. It confirms that within Badulla, mass movements are triggered by very high intense and/or long duration rainfalls events only. Further, time series analysis of the rainfall events shows an upward trend of extreme rainfall events, which increased landslide occurring frequency in last six (6) years.
\end{abstract}

\section{Keywords}

Rainfall Intensity-Duration, Rainfall Threshold, Landslide, Debris Flow, 


\section{Introduction}

Landslide (mass movements) acts on natural and engineered slopes in steep topography [1] [2]. Rainfall and Earthquakes are main triggering factor for mass movements [3] [4] [5] [6], however the rock type, type of bedrock, type of cover material, geotechnical and hydrogeological properties, land use, slope gradient, slope shape, and so on can be considered as contributory other contributory factors [3] [7] [8] [9] [10]. Sri Lanka is located in earthquake free zone [11] Therefore in Sri Lankan contest, rainfall can be considered as a main landslide triggering factor.

Various methods have been proposed in the literature to predict rainfall conditions that are expected to trigger mass movements [5] [12] [13]. These studies have been focused on rainfall parameters such as rainfall intensity, duration, cumulative rainfall, and antecedent rainfall [12]. Relationships between rainfall intensity and duration are the most common estimate of rainfall thresholds for landslides [14] [15] [16]. In case of rainfall-induced landslides, the minimum intensity or duration of rainfall necessary to cause or reactivate a landslide is known as the "rainfall threshold for sliding" [17]. Empirical rainfall thresholds for the initiation of landslides have been proposed at the global (world-wide), regional, and local scale. Review of the literature reveals that no unique set of measurements exists to characterize the rainfall conditions that are likely. Different types of empirical rainfall thresholds for possible initiation of landslides are proposed in the literature. However, most of the similar studies in the Indian subcontinent have established intensity-duration (ID) thresholds, thresholds based on the total event rainfall, and rainfall event-duration thresholds [18].

Badulla district in Sri Lanka is one of the major districts where large-scale landslides are observed during heavy rainfall (Figure 1) [19]. Several studies have focused on understanding the underlying landslide triggers in the country [20]. Generally, a continuous rainfall about $200 \mathrm{~mm}$ within a period of 3 days makes hilly districts susceptible to landslides [21]. However, around two-day continues $75-100 \mathrm{~mm}$ rainfall can trigger landslides in sloped cultivated lands in Badulla [22]. In Sri Lanka, an increasing trend in high intense rainfall event during last decade is recorded, especially in the Wet Zone and western slopes in the central hills [23]. Also, the frequency of landslide events per year has increased over the last few decades. A sudden increase is observed in the occurrence of landslides during the period from 2002 to 2008 in Badulla [24]. However, studies have not been focused to establish a relationship between rainfall intensity and duration.

The rainfall intensity and duration analyses are important to study the sliding trends during the past, and such analyses can help to forecast future events under 


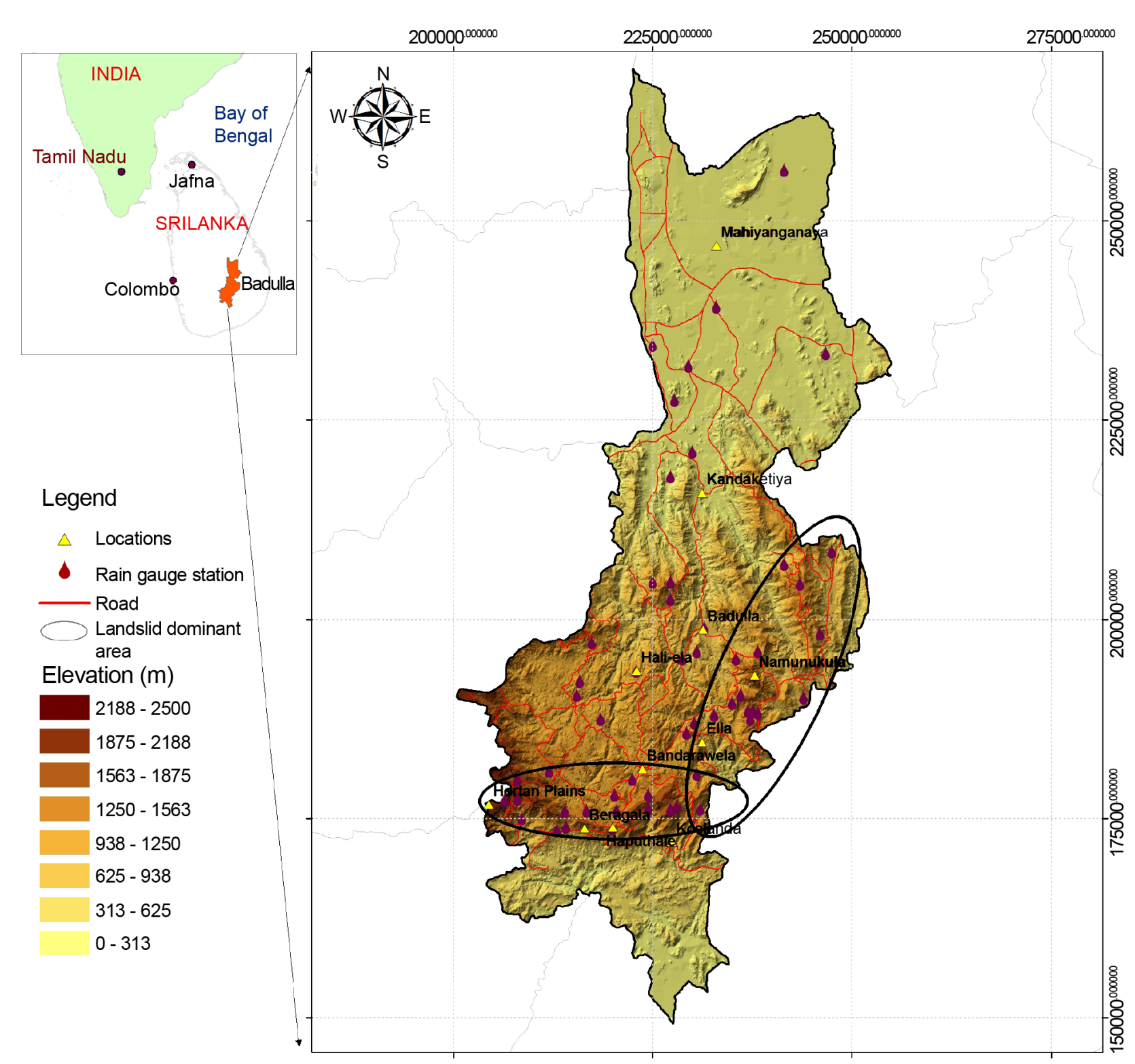

Figure 1. Map showing elevation distribution of Badulla district and location of rain gauge stations. Triangles denote important locations for past landslides. Elevations based on 1:50 000 maps (1998) Department of Survey, Sri Lanka.

heavy rainfall. Therefore, the major aim of this study is to investigate the rainfall variation in the last few decades and to study the temporal pattern of landslides. Further, the study expects to analyze rainfall events that have caused landslides in Badulla, to define the threshold for possible occurrence of landslides.

\section{Study Area and Physical Setting}

Badulla is about $230 \mathrm{~km}$ away from Colombo towards the eastern slopes of the central hills of Sri Lanka (Figure 1).

\subsection{Demography and Geographical Description of the Area}

The population of Badulla district is approximately 886,000 , with $1: 1$ male to 
female ratio. Although $47 \%$ of residents are employed, the high rate of dependency reaches $54 \%$ of the population [25]. Fifty percent of the population is included in the labor force due to the large number of employees in plantation agriculture. Badulla has been recognized as one of the districts with highest poverty levels with lower per capita income [26].

Badulla district is located in the southeastern mountainous terrain in Sri Lan$\mathrm{ka}$ and represents an area of $2870 \mathrm{~km}^{2}$ (Figure 1). Physiographically, it is a complex region with mountain peaks, dissected plateaus, escarpments, and narrow valleys. Most mountains are extended from middle to southern area, whereas the northern area of the district is demarcated by a flat terrain (Figure 1). The eastern mountain region of the district has an elevation range from 1200 to $1800 \mathrm{~m}$. The north-south aligned a mountain range link to well-known Namunukula and Lunugala ranges that rise to over $1200 \mathrm{~m}$. The extreme south of the district demarcated by a steep escarpment is a section of the Koslanda plateau with an elevation of $300-1000 \mathrm{~m}$ above mean sea level (Figure 1).

\subsection{Climatic Conditions of the Area}

Rainfall over Sri Lanka is characterized by its tropical location and by the monsoonal regime, and thus has a significant seasonal variation in the rainfall pattern. There are four climatologic seasons in Sri Lanka, namely, the northeast monsoon from December to February, the southwest monsoon from May to September, the first inter-monsoon from March to April, and the second inter-monsoon from October to November. The north-east monsoon provides a high rainfall to the eastern slopes, but the south-west monsoon and inter-monsoon is relatively dry $(500-750 \mathrm{~mm})$. The average annual rainfall of Badulla is around $2000 \mathrm{~mm}$ and has a clear variation along the terrain. Northern and southern-most extremities have $900 \mathrm{~mm}$ annual average and Uva Basing has $1700 \mathrm{~mm}$. However, over $2500 \mathrm{~mm}$ is in the eastern Namunukula and Lunugala ridges [27].

The rainfall regimes differ with the region's geography. The northern-most tips of the Lunugala ridges received $40 \%-50 \%$ of the annual rainfall by north-east monsoons, $30 \%-40 \%$ during the inter-monsoons, and $12 \%-20 \%$ in south-west monsoons [27]. Especially the rain shadow areas of Uva Basin receive maximum rainfall during the inter-monsoons. In general, Badulla and Diyatalawa cities have $43 \%$ - $47 \%$ of the total annual rainfall during the inter-monsoons (March-April and October-November), 35\% and north-east monsoons, and $22 \%$ during the south-west monsoon (December-February). However, along the southern and eastern edges of the basin, south-west monsoon exceeds the north-east.

\subsection{Geology and Land Use around the Landslides}

Precambrian high-grade metamorphic rocks in Sri Lanka belong to three major geological units known as the Highland, Wanni, and Vijayan Complexes. Badul- 
la district is located in the eastern section of the Highland Complex, which is composed of meta-igneous rocks and meta-sedimentary rocks [28]. The meta-igneous rocks comprise granitic, charnockitic, and quartzofeldspathic gneisses, along with metabasites and syenitic gneiss [29]. The meta-sedimentary rocks are mostly meta-pelites, meta-arkoses, and meta-greywackes [30]. However, north-east flat region of the district consist of Wanni Complex rocks.

With respect to spatial distribution, most landslides appear to occur in the Uva, Central, and Southern, provinces. Especially, Badulla, Nuwara Eliya, Kegalle, Rathnapura, Galle, Matara, and Kalutara are the most landslide prone districts. In general, higher incidences are reported within the Badulla district. In addition, approximately $66.9 \%$ of the land area in Badulla district is prone to landslides [22] therefore, Badulla is considered as one of the landslide prone districts of Sri Lanka.

Land use of Badulla district is mostly covered by scrubs $\left(\approx 790 \mathrm{~km}^{2}\right)$, home gardens $\left(\approx 582 \mathrm{~km}^{2}\right)$, and forests $\left(\approx 335 \mathrm{~km}^{2}\right)$. Main plantations around hilly regions are tea cultivations $\left(\approx 890 \mathrm{~km}^{2}\right)$ while flat terrain in the northern region is predominant by paddy lands ( $\approx 270 \mathrm{~km}^{2}$ [25] [27]).

\section{Methodology}

The methodology used in this study mainly consisted of two components: 1) collection of landslide and rainfall records in Badulla district from 1986 to 2014 and evaluate the trend and patterns of the landslide occurrences and rainfall variability; and 2) analysis of the relationship between rainfall and landslide occurrence using empirical models. Data was collected from NBRO and Metrological Department of Sri Lanka. The parameters and analysis model were obtained from the referred from previous international studies.

\subsection{Mass Movement Database}

A total of 44 mass movements caused by rainfall events were analyzed during the 28 years from 1986 to 2014. Mass movement data were compiled from NBRO Sri Lanka. NBRO has been classified Mass movement events based on material type and type of movement in such a way that, Debris flow, Rock fall, Cutting failure, Earth slip, and Landslide. Temporal variability of different types of landslide events and corresponding annual average rainfall illustrated in Figure 2.

Further secondary data was collected including the type of the landslide, location, and approximate time which mass movement taken place (to the closest hour) of each event and summarized in a table.

\subsection{Site Selection, and Incorporate Mass Movement Data into Rainfall}

Rainfall records were obtained from 54 rain-gauge stations located within the district established by Metrological Department and National Building Research Organization (NBRO) of Sri Lanka. This data series provided records of rainfall 


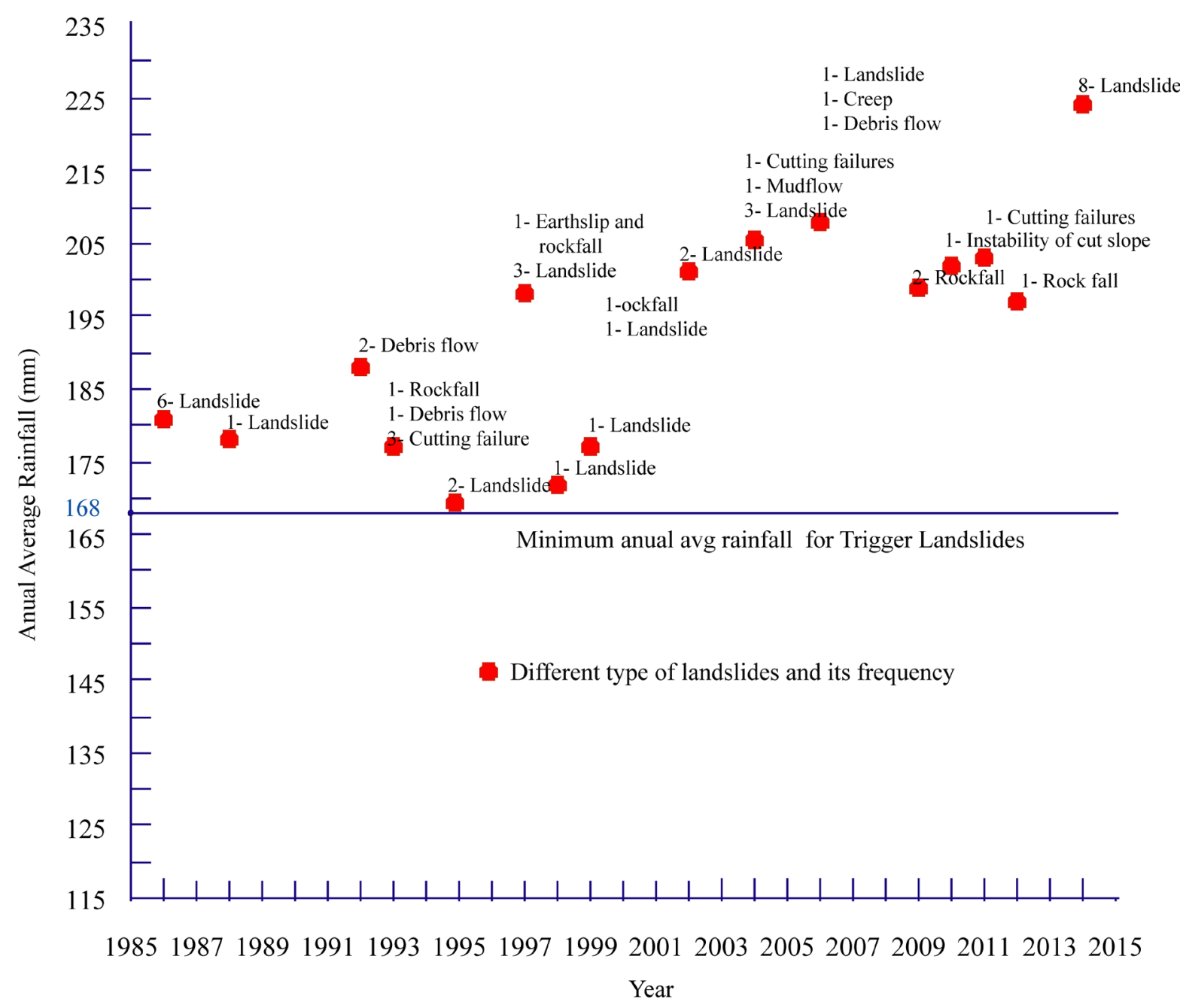

Figure 2. Figure shows the seasonal distributions of large scale landslides: from 1986 to 2014 based on source Meteorological Department and NBRO, Sri Lanka.

data of 28 years including occurrences of mass movements. Mass movements, for selected rainfall was verified by using archival newspapers and remote sensing data. According to NBRO, 44 mass movements had been occurred during the considered period from 1986 to 2014. Because of that, hourly cumulative rainfall $72 \mathrm{hrs}$ prior to the taken place each and every mass movements, and the duration (hrs) of that rainfall were obtained from the located rain-gauge stations belongs to Metrological Department and NBRO of Sri Lanka.

\subsection{Estimation of the Causative Amount of Rainfall}

Throughout the preliminary field survey and satellite image observation, it is observed that rain gauges stations are not always exactly located close to mass movement sites however, to threshold analysis, the cumulative rainfall and duration of rainfall for triggering each mass movement is essential [31]. Therefore, to estimate the causative amount of rainfall for each and every 44 landside events in Badulla from 1986 to 2014, interpolation technique was adopted within the GIS 
environment. The interpolation ordinary Kriging and a spherical semi-variogram model were used to estimate hourly rainfall data at each landslide location over the duration of a rainfall event. Ordinary Kriging and a spherical semi-variogram model can be considered as most accurate methods to estimate rainfall in mountainous areas in Sri Lanka [32]. A continuous rainfall event is considered to begin when hourly rainfall surpasses $4 \mathrm{~mm}$ and ends when hourly rainfall decreases below $4 \mathrm{~mm}$ over the next six consecutive hours [33].

\subsection{Threshold Analyses}

A threshold is defined as the level or the value that must be exceeded to produce a given effect or result [34]. Rainfall thresholds for mass movement are defined as the best separators of rainfall conditions that resulted and did not result in slope instability. Rainfall thresholds for mass movement can be modeled by establishing relationship between rainfall and intensity, further it can be used to predicted possibility to mass movements under the rainy conditions [35].

In this study the causative amount of mean rainfall $(\mathrm{mm})$ and consequent duration (hr) were obtained from the beginning of each of 44 rainfall events to the time of mass movement occurrence. The mean rainfall intensity per hour (I, $\mathrm{mm} / \mathrm{hr}$ ) was calculated for each mass movement (Table 1). The rainfall amount varies largely depending on the main reliefs of the Badulla region under such circumstances it is better use mean rainfall rather than peal rainfall [36].

International literature revealed that various methods have been used to establish the relationship between rainfall intensity and duration [12] [37], however the general form of the relationship between rainfall intensity and duration given as an exponential function as in follows

$$
I=\alpha \cdot D^{-\beta}
$$

i.e., a simple exponential function, where $\alpha$ is a scaling constant (intercept), and $\beta$ is the shape parameter (slope). The Equation (1) is commonly used for model the Intensity and Duration in many studies.

Exponential equations can be written as logarithmic equations and vice versa. In this study exponential rainfall intensity and duration relationship $\left(I=\alpha \cdot D^{-\beta}\right)$ were converted into linear form, because linear model can overcome the problems associated with the fitting of data into exponential form. For that exponential function transformed into logarithmic form as given below

$$
\ln (I)=\ln (\alpha)-\beta \ln (D)
$$

Equation (2) is the liner form of the Equation (1). Rainfall intensity $(I)$ and duration $(D)$ was $\log$ transformed and then a plotted $\ln (I)$ against $\ln (D)$ for 44 rainfall events from 1986 to 2014 in same graph. This liner function (I-D) has been empirically proved for a wide range of time durations [14]. Variability difference mass movement types (debris flow, landslides, mud flow, slope failures, etc.) related to each rainfall events were illustrated by different colors in the $\ln (I)$ vs. $\ln (D)$ as shown in Figure 3. 


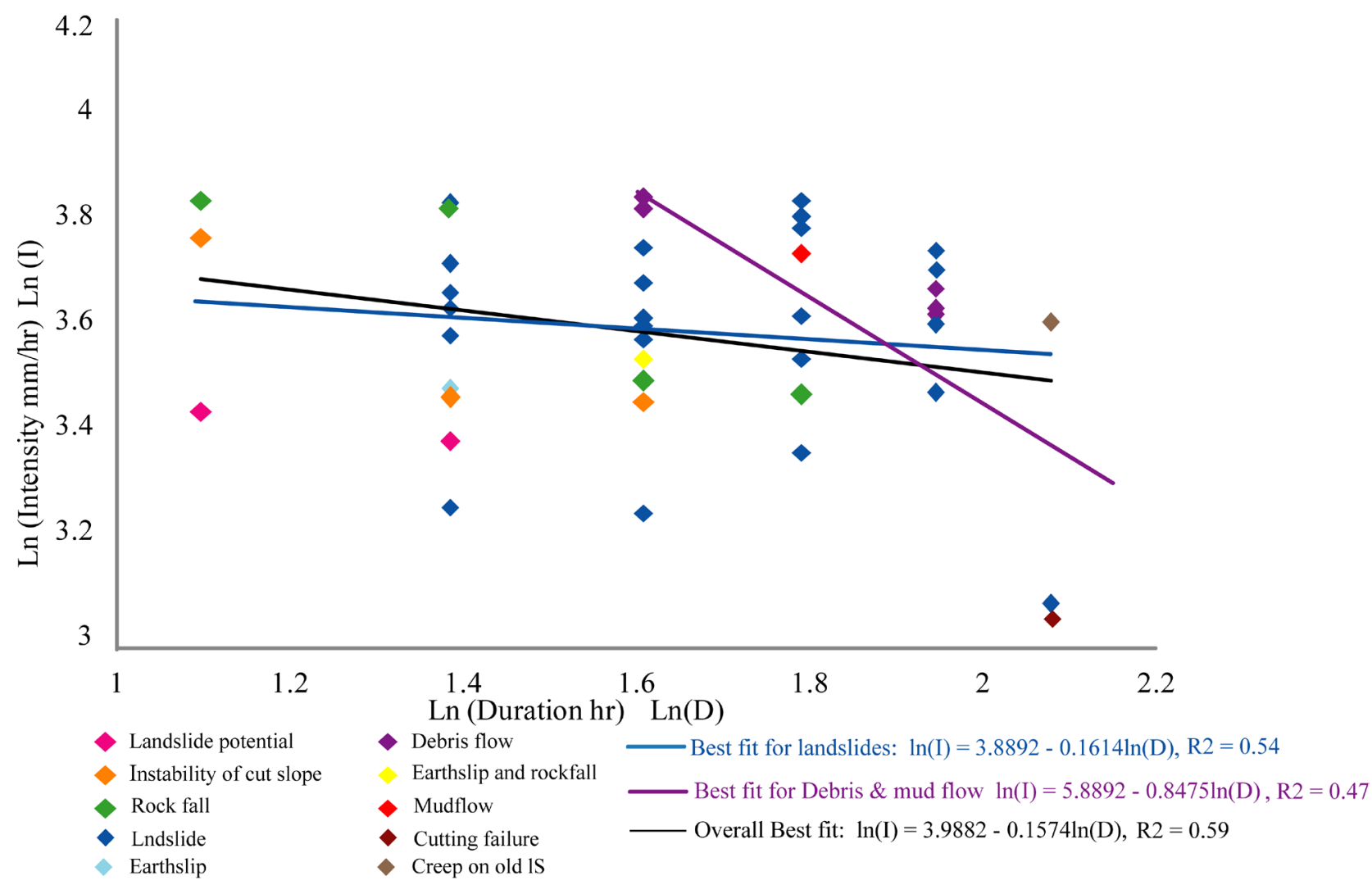

Figure 3. Discrimination plot of critical rainfall intensity-duration for Badulla district.

Rainfall conditions, $\ln (I)$ vs. $\ln (D)$, that have resulted in landslides is fitted (least square method) with a linear equation of the type $\log (D)=\log (\alpha)-\beta \log (D)$ which is entirely equivalent to the exponential function in linear coordinates. Then log-linier regression model was established for most common mass movement types in Badull district.

The Independent Samples $t$ Test was conducted compares the means of rainfall intensity of landslides and means of rainfall intensity of Mud/debris flow in order to determine whether there is statistical evidence that the associated population means are significantly different.

\subsection{Analyses of Temporal Variability of Rainfall and Landslides}

Annual average daily rainfall and landslide data were analyzed for the period from 1986 to 2014 in Badulla district. Trend analysis examined the variation in rainfall and landslide patterns using Minitab 20 (Minitab Inc). Nonparametric Chi-Square goodness of fit test was employed to study the association between month (season) and occurrence of landslides using SPSS 19 ( $\mathrm{p}<0.05)$.

Temporal variation of landslide events is therefore vital to determine the significance of the landslide trend, and nonparametric Mann-Kendall test was conducted using SPSS $19(\mathrm{p}<0.05)$. The calculations are described below:

$$
S=\sum_{i=2}^{n} \sum_{j=1}^{i-1} \operatorname{singn}\left(x_{i}-x_{j}\right)
$$


where, $S$ is the sum of signs of differences between any two observations for a series $X_{n}$. Also, where sign $(z)$ is 0 when $z$ is zero, and 1 when $z>$ and -1 when $z<1$.

\section{Results and Discussion}

In the considered period, i.e. from 1986 to 2014, the rainfall pattern in Badulla depicted a noticeable change; analogous to the rainfall change, landslide occurrences also showed an increasing trend having two events per year. A threshold was fitted to the liner form of I-D curve, expressed as $\ln (I)=3.9882-0.1570$ $\ln (D)$.

\subsection{Rainfall Intensity-Duration (I-D) Threshold}

The I-D threshold for mass movements is identified on an I-D plot as the minimum rainfall for which a landslide could occur (Chen, 2015).

Thresholds for the possible initiation of rainfall-induced landslides in the $\mathrm{Ba}$ dulla district were identified from the log-linier model of the I-D exponential function. Mean rainfall intensity for all mass movements ranged from $25 \mathrm{~mm} / \mathrm{h}$ to $54 \mathrm{~mm} / \mathrm{h}$ with an average of $42 \mathrm{~mm} / \mathrm{h}$, and rainfall duration ranged between 3 - $8 \mathrm{~h}$ with an average of $5 \mathrm{~h}$ (Table 1 ). Minimum cumulative rainfall was 119 $\mathrm{mm}$ and the maximum was $339 \mathrm{~mm}$ with an average of $107 \mathrm{~mm}$. A considerable range of rainfall durations and cumulative rainfall suggests that different meteorological and hydrological conditions are likely to initiate landslides within the Badulla district.

Average rainfall intensity, duration, and cumulative rainfall for debris flow/mud flow were $49 \mathrm{~mm} / \mathrm{h}, 7 \mathrm{~h}$, and $260 \mathrm{~mm}$ respectively, and those for landslides were $41 \mathrm{~mm} / \mathrm{h}, 5 \mathrm{~h}$, and $210 \mathrm{~mm}$ respectively (Table 1 ).

This study established an empirical linear regression line I-D plot, considering all 44 mass-movement events summarized in Table 1, landslide and debris/mud flow separately, and thresholds were established for overall mass movements, landslides and debris/mud flow for Badulla district (Figure 3). The resultant linear regression equations for these three conditions are as follows:

$\operatorname{Ln}(I)=3.9882-0.1570 \ln (D)\left(3<D<8\right.$ h; all mass movements, $\left.R^{2}=59 \%\right)$

$\operatorname{Ln}(I)=3.8892-0.1614 \ln (D)\left(5<D<8 \mathrm{~h}\right.$; landslides only, $\left.R^{2}=54 \%\right)$

$\operatorname{Ln}(I)=5.8892-0.8475 \ln (D)\left(5<D<8 \mathrm{~h}\right.$; debris \& mud flow only $\left.R^{2}=47 \%\right)(6)$

This threshold are fitted to the mean values of the data point reflects the approximate average rainfall conditions necessary to trigger any mass movement in Badulla district. The equation for all mass movements (Equation (4)) indicates that short duration $(<2 \mathrm{~h})$ and high-intensity $(>53.75 \mathrm{~mm} / \mathrm{h})$ rainfall events can potentially trigger any mass movement in Badulla district. However, long-duration $(>8$ h) and low-intensity $(<24.6 \mathrm{~mm} / \mathrm{h})$ rainfall events may also trigger mass movements in Badulla district.

Independent sample t-test and resultant p-values $(<0.05)$ indicate that mean 
Table 1. Date of occurrences and rainfall characteristics of 42 rainfalls that trigger the landslides in Badulla.

\begin{tabular}{|c|c|c|c|c|c|c|}
\hline \multirow[t]{2}{*}{ Year } & \multirow[t]{2}{*}{ Month } & \multirow[t]{2}{*}{ Date } & \multicolumn{4}{|c|}{ Landslide information } \\
\hline & & & Avg. Accumulation mm & Duration hr & Avg. Intensity mm/hr & Type \\
\hline 1986 & January & 6 & 316 & 7 & 45 & Landslide \\
\hline 1986 & January & 7 & 259 & 7 & 37 & Landslide \\
\hline 1986 & January & 9 & 119 & 4 & 30 & Landslide \\
\hline 1986 & January & 9 & 244 & 5 & 49 & Landslide \\
\hline 1986 & January & 10 & 237 & 6 & 40 & Landslide \\
\hline 1986 & January & 10 & 197 & 5 & 39 & Landslide \\
\hline 1986 & January & 10 & 205 & 5 & 41 & Landslide \\
\hline 1988 & December & 21 & 165 & 4 & 41 & Landslide \\
\hline 1992 & November & 16 & 319 & 7 & 46 & Debris flow \\
\hline 1992 & November & 16 & 305 & 7 & 44 & Debris flow \\
\hline 1993 & December & 16 & 310 & 6 & 52 & Debris flow \\
\hline 1993 & December & 17 & 179 & 4 & 45 & Rockfall \\
\hline 1993 & December & 26 & 198 & 8 & 25 & Cutting failure \\
\hline 1995 & April & 17 & 212 & 4 & 53 & Landslide \\
\hline 1995 & July & 24 & 228 & 5 & 46 & Landslide \\
\hline 1997 & November & 17 & 257 & 6 & 43 & Earth slip \\
\hline 1997 & November & 19 & 268 & 5 & 53 & Landslide \\
\hline 1997 & November & 19 & 289 & 6 & 48 & Landslide \\
\hline 1997 & November & 19 & 215 & 4 & 54 & Landslide \\
\hline 1998 & November & 16 & 149 & 3 & 50 & Landslide \\
\hline 1998 & November & 17 & 180 & 4 & 45 & Landslide \\
\hline 1999 & October & 5 & 147 & 5 & 29 & Landslide \\
\hline 2002 & April & 23 & 198 & 6 & 33 & Landslide \\
\hline 2002 & April & 24 & 206 & 5 & 41 & Landslide \\
\hline 2004 & December & 21 & 198 & 6 & 33 & Cutting failures \\
\hline 2004 & December & 22 & 182 & 5 & 36 & Cutting failures \\
\hline 2004 & December & 23 & 211 & 5 & 42 & Landslide \\
\hline 2004 & December & 23 & 320 & 6 & 53 & Mudflow \\
\hline 2006 & November & 22 & 307 & 7 & 44 & Landslide \\
\hline 2006 & December & 20 & 338 & 8 & 42 & Creep on old IS \\
\hline 2006 & December & 20 & 316 & 7 & 45 & Debris flow \\
\hline 2009 & January & 20 & 199 & 5 & 40 & Rock fall \\
\hline 2009 & January & 20 & 189 & 4 & 47 & Rock fall landslide \\
\hline 2010 & January & 26 & 160 & 3 & 53 & Instability of cut slope \\
\hline 2011 & November & 23 & 221 & 6 & 37 & Cutting failures \\
\hline 2012 & December & 21 & 160 & 3 & 53 & Rock fall \\
\hline 2014 & October & 29 & 306 & 6 & 51 & Landslide-Mud flow \\
\hline 2014 & October & 30 & 197 & 8 & 25 & Landslide \\
\hline 2014 & October & 30 & 174 & 4 & 44 & Landslide \\
\hline 2014 & October & 30 & 149 & 4 & 37 & Earth slip \\
\hline 2014 & October & 30 & 189 & 5 & 38 & Landslide \\
\hline 2014 & October & 30 & 107 & 3 & 36 & Landslide potential \\
\hline 2014 & October & 30 & 149 & 4 & 37 & Instability of cut slope \\
\hline 2014 & October & 30 & 135 & 4 & 34 & Landslide potential \\
\hline $\operatorname{Max}$ & & & 338 & 8 & 54 & \\
\hline $\min$ & & & 107 & 3 & 25 & \\
\hline Avg. & & & 218 & 5.3 & 42.2 & \\
\hline Std & & & 62 & 1 & 8 & \\
\hline
\end{tabular}


rainfall intensity of landslides and mean rainfall intensity of debris/mud flows are significantly different at $95 \%$ confidence level.

\subsection{Comparing I-D Thresholds for Badulla with Those of Other Part of the World}

Established empirical I-D thresholds for mass movements in Badulla from all type of mass movements, landslide and debris/ mud flow were compared with those for other areas of the world is essential.

Worldwide threshold for debris flows developed by Caine (1980), log liner form that worldwide threshold given by $\ln (I)=2.6959-0.92 \ln (D)$. This worldwide threshold falls below the Badulla it indicates much rainfall required to trigger any mass movement in Badulla with compared to the global scenario.

[12] (2015) established thresholds for all mass movements, landslides and debris flows in Taiwan, The equation for all mass movements show that short-duration (e.g., $16.1 \mathrm{~mm} / \mathrm{h}$ ) rainfall events can trigger mass movements at any time. But, low-intensity (e.g., $<8.8 \mathrm{~mm} / \mathrm{h}$ ) rainfall events required long-duration (e.g., $>71$ h) for trigger mass movements. When compared to Sri Lankan mass movements triggering threshold intensities are fairly higher than the Taiwanese threshold values. It confirms that within Badulla, mass movements are triggered by very high intense and/or long duration rainfalls events only with compared to Taiwan.

\subsection{Temporal Distribution of Rainfall and Landslides}

Figure 4 presents the annual average rainfall variation, which illustrates a one direction upward trend in weather pattern changes over the last 28 years. The rainfall distribution pattern revealed a $172 \mathrm{~mm}$ annual average mean with 32 $\mathrm{mm}$ of standard deviation, while showing $43 \%$ of fairly high coefficient of variance. However, after year 2000, coefficient of variance was recorded as $63 \%$, indicating highest rainfall variability than the previous years.

Such unusual rainfall patterns resulted in heavy rainfall events and dry spells throughout the last 28 years, and this uncertainty trend of rainfall was rapidly amplified after year 2000 (Figure 4). Overall positive direction of mean deviation of rainfall indicates that higher probability in extreme rainfall events in the future, which was a common phenomenon in landslide prone areas [6]. According to previous studies, Badulla district is vulnerable to climatic changes and it already drives an increase in extreme weather events in the future [38].

However, the data displays a sudden positive mean deviation of average rainfall during the period of 2000 to 2014 (Figure 4). This pattern has a closer relationship to the temporal distribution of mass movements during the considered period (Figure 5). This may conclude that frequently high mean deviation of rainfall results higher probability to occur mass movements.

During the period of 1986-2014, 44 large scale mass movement events were clearly identified and recorded in table (Table 1). According to Figure 5 and 

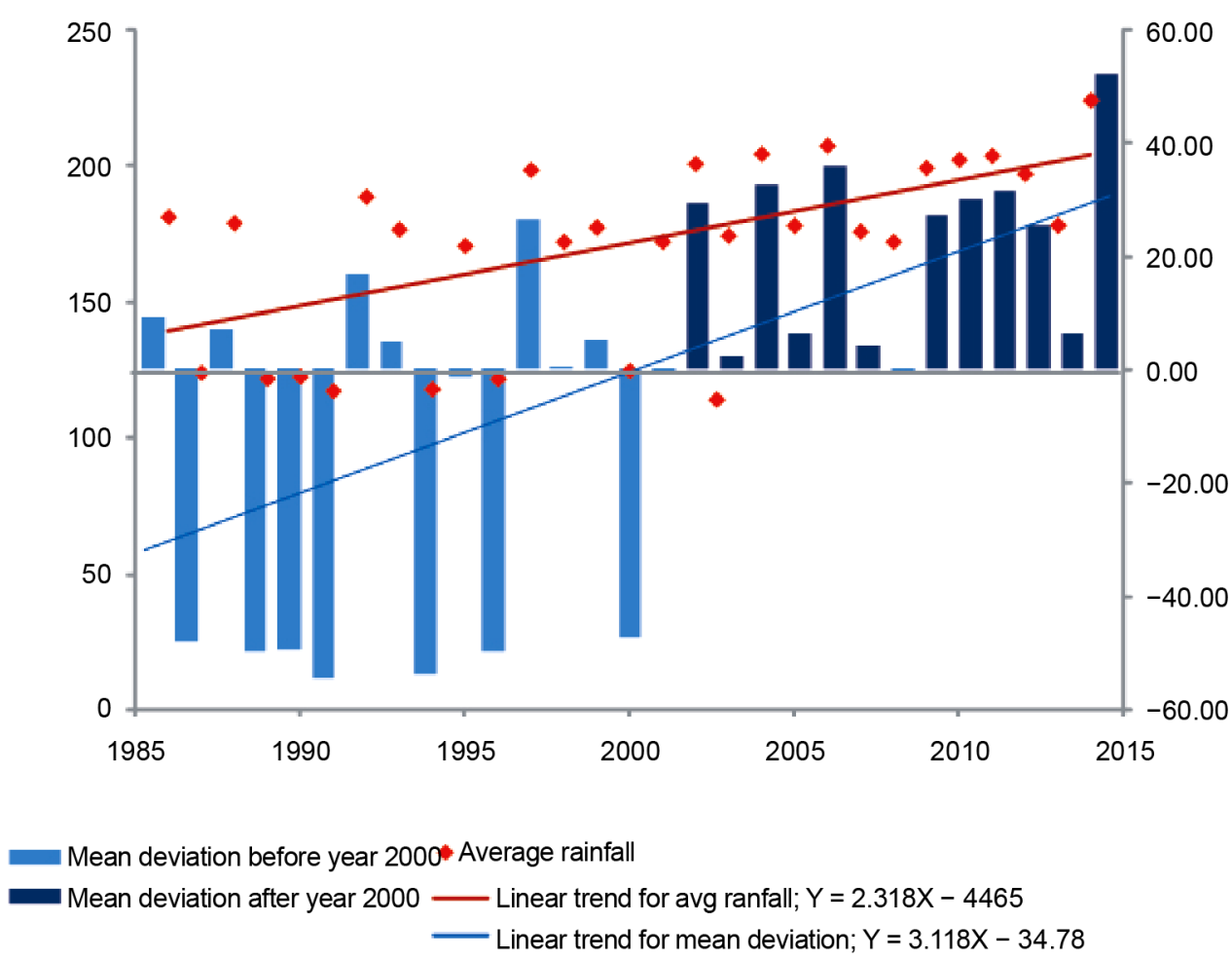

Figure 4. Bar chart shows the annual average rainfall and mean deviation from 1986 to 2014 for Badulla district.

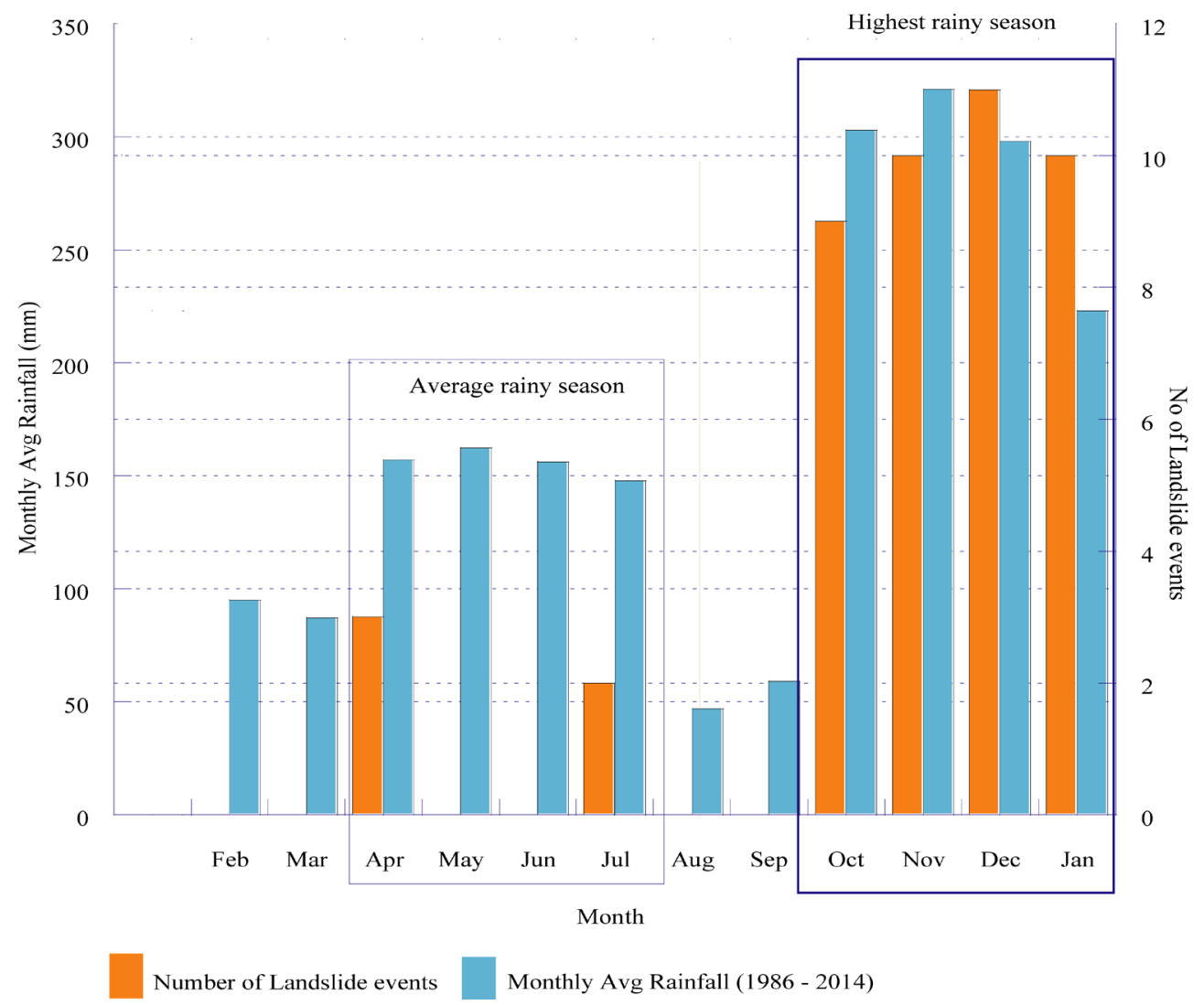

Figure 5. Bar chart shows temporal variability of large scale landslides in Badulla from 1986 to 2014. 
Table 1, from 1986 to 2000, only 20 incidents were recorded while lowering annual average of mass movements to 2 incidents per year. Although totally 24 incidents were recorded from 2000 to 2014, it exceeded the annual average of mass movements occurrences to over two incidents per year. Temporal variability of mass movements demonstrated an upward trend of mass movement events from 1986, while showing 0.12 events per month.

According to the Mann-Kendall test, landslide trend is significant at 95\% confidence level. If this rainfall trend and mass movement pattern will continue to the future, it can be conclude that landslides hazards in Badulla may be higher than the past decades. Sri Lankan government also prophesied that rise of landslides in Badulla due to the extreme rainfall events from year 2000 to future.

\subsection{Impact of Seasonal Rainfall Variation on Landslides}

Generally, mass movements are more common during rainy sessions in Sri Lanka, and thus seasonal distribution of mass movements demonstrate a clear link with the seasonal variation of rainfall (Figure 5). Highest rainfall is received in northeast monsoon (November to January) and first inter-monsoon (April to July), which is reflected in the seasonal variation of landslides (Figure 5).

The records of landslides are high in the months of April, May, and July, and once again from November to January, indicating a clear relationship with first inter-monsoon and northeast monsoon seasons respectively (Figure 5). According to Metrological Department, Sri Lanka, approximately 60\% - 80\% of rainfall is received during the northeast monsoon; therefore, the northeast monsoon period (November to January) has the highest recorded landslides occurrences than the first inter-monsoon period in Badulla. According to this study, approximately $80 \%$ of mass movements occurred in northeast monsoon period. Graphically it can be proved that there is a clear link between climatic seasons and occurrences of mass movements. According to Chi-Square goodness test there is a significant relationship exist between monsoon period, and the occurrence of landslide at $95 \%$ confidence level $(\mathrm{p}<0.05)$.

\subsection{Possible Average Conditions for the Occurrence of Landslides}

In Sri Lanka, landslide process begins with rainfall but is affected by many other factors; therefore it is impossible to determine the possible rainfall level to initiate landslides. This study revealed that landslides are a result of heavy precipitation and when average monthly rainfall exceeds $168 \mathrm{~mm} / \mathrm{month}$, the occurrence of landslides becomes more dominant in the district. Worldwide studies have shown that this value may vary from $150 \mathrm{~mm} / \mathrm{month}$ to $200 \mathrm{~mm} / \mathrm{month}$ in the global context [39]. Nonetheless, according to few cases of the present study, even if rainfall exceeded $168 \mathrm{~mm} /$ month, no landslides were observed (Figure 6).

This may be due to the role played by predisposing factors such as proper land management practices and stable geological settings. However, no recorded landslide below $168 \mathrm{~mm} / \mathrm{month}$ level is available during the last 28 years. 


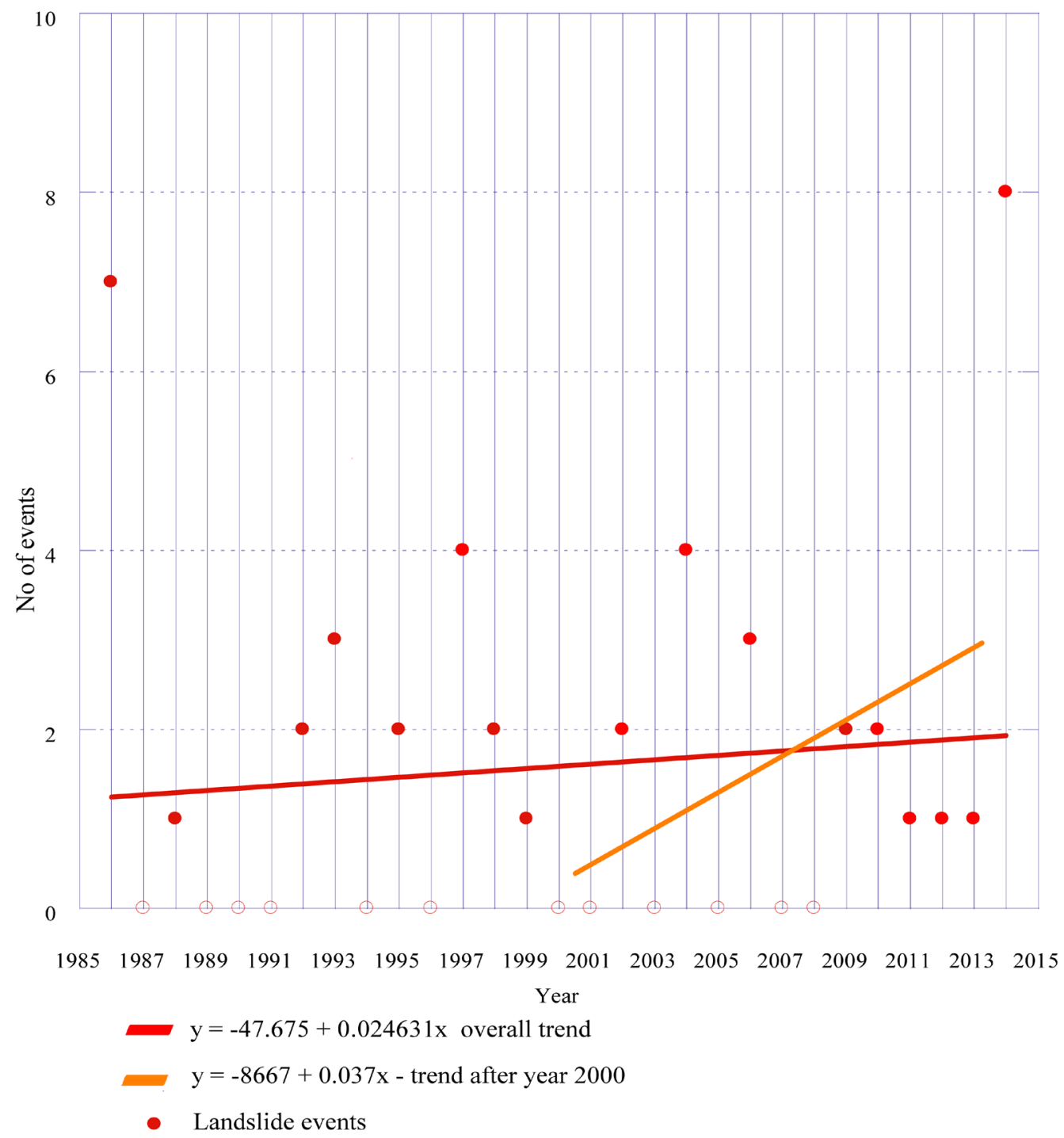

Figure 6. Scatter plot represents monthly average rainfall from 1986 to 2015. Red dots denote large scale landslides.

\subsection{Limitations of the Study}

Developed log-linear model can determine the amount of precipitation needed to trigger landslide in Badulla district. However, limitations exist. In study, log-liner model developed by studying individual rainfall events and corresponding landslides however, other landslide initiation control factors such as morphological, lithological differences, soil characteristics, human activities have not been considered. But these data are difficult to collect and model precisely over large areas. Developed log-linear model can be calibrated using rainfall events for which precipitation measurements and the location and the time of slope failures are known.

Regional and local ID thresholds are the fact that thresholds defined for a specific administrative region in this study it was Badulla district. If ID thresholds based on specific administrative region then it would not be possible to export it 
for surrounding regions. Therefore it is recommended to consider climatological boundaries rather than the administrative boundaries in further studies.

\section{Conclusions}

This study confirmed that most landslides occur in Badulla district during northeast monsoons and inter-monsoon seasons and indicated that a strong correlation exists between frequency of landslides and rainfall seasons of the district. The rainfall shows increasing trends in Badulla district within last three decades. This could indicate the amount of rainfall per day may have increased. In particular, the number of landslides occurred per year increased over the period of 28 years. However, the sudden upsurge on landslide occurrences from 2002 to 2014 can be due to the increase of rainfall intensity during that period. This study could conclude a direct proportional relationship between the amount of rainfall per day and the frequency of landslide events in Badulla district. This will lead to the potential landslide hazards having an increasing trend.

The established I-D threshold reveled that short-duration rainfall events and higher mean rainfall intensities were required to trigger debris/mud flow, while long-duration rainfall events can trigger both landslide and debris flow with almost the low rainfall intensity. This study also demonstrated the importance of peak rainfall intensity to trigger any type of mass movement in Badulla. Generally, most mass movements (83\%) occurred within 5 - $6 \mathrm{~h}$ of peak rainfall.

Comparing our I-D thresholds with those from other areas of the world shows that the I-D threshold for Badulla is relatively high, particularly for long-duration rainfall events. As Taiwan is characterized by high-relief topography and complex geology (Figure 1), both of which facilitate mass movements, this observation seems contradictory. Thick forest cover in the Badulla district had minimized the impact of heavy rainfall to trigger the mass movements. Therefore, lands in the region are well adjusted to the extreme climatic conditions of the region with compared to other part of the world.

Badulla district is more vulnerable to deforestation and forest degradation as results of human activities. Reduction of forest cover may cause to change the rainfall threshold value for mass movement in the region that will increase landslide hazard within the district.

\section{Acknowledgements}

We thank Mr. A.L.K. Wijemannage from Department of Meteorology, Sri Lan$\mathrm{ka}$, for access to rainfall data. We also acknowledge the Director General of National Building Research Organization for the great support by providing land slide information. This study was supported by Faculty of Graduate Studies, University of Sri Jayewardenepura, for Ph.D. candidate Mr. E. N. C. Perera.

\section{References}

[1] Hungr, O., Leroueil, S. and Picarelli, L. (2014) The Varnes Classification of Landslide Types, an Update. Landslides, 11, 167-194. 
https://doi.org/10.1007/s10346-013-0436-y

[2] Zhuang, J., Peng, J., Iqbal, J., Liu, T., Liu, N., Li, Y. and Ma, P. (2015) Identification of Landslide Spatial distribution and Susceptibility Assessment in Relation to Topography in the Xi'an Region, Shaanxi Province, China. Frontiers of Earth Science, 9, 449-442. https://doi.org/10.1007/s11707-014-0474-3

[3] Wu, L.Z., Selvadurai, A.P.S., Zhang, L.M., Huang, R.Q. and Huang, J. (2016) Poro-Mechanical Coupling Influences on Potential for Rainfall-Induced Shallow Landslides In Unsaturated Soils. Advances in Water Resources, 98, 114-121. https://doi.org/10.1016/j.advwatres.2016.10.020

[4] Gariano, S.L. and Guzzetti, F. (2016) Landslides in a Changing Climate. Earth Science Reviews, 162, 227-252. https://doi.org/10.1016/j.earscirev.2016.08.011

[5] Vasu, N.N., Lee, S., Pradhan, A.M.S., Kim, Y., Kang, S. and Lee, D. (2016) A New Approach to Temporal Modeling for Landslide Hazard Assessment Using an Extreme Rainfall Induced-Landslide Index. Engineering Geology, 215, 36-49. https://doi.org/10.1016/j.enggeo.2016.10.006

[6] Saito, H., Murakami, W., Daimaru, H. and Oguchi, T. (2017) Effect of Forest Clear-Cutting on Landslide Occurrences: Analysis of Rainfall Thresholds at Mt. Ichifusa, Japan. Geomorphology, 276, 1-7. https://doi.org/10.1016/j.geomorph.2016.09.024

[7] Bromhead, E.N. and Ibsen, M.L. (2007) An Overview of Landslide Problems in the British Isles, with Reference to Geology, Geography and Conservation. In: Sassa, K., Fukuoka, H., Wang, F.W. and Wang, G.H., Eds., Progress in Landslide Science, Springer, Berlin, Heidelberg, 13-25. https://doi.org/10.1007/978-3-540-70965-7_2

[8] Sassa, K. (2005) Landslide Disasters Triggered by the 2004 Mid-Niigata Prefecture Earthquake in Japan. Landslides, 2, 243. https://doi.org/10.1007/s10346-005-0063-3

[9] Regmi, A.D., Yoshida, K. and Dhital, M.R. (2013) Effect of Rock Weathering, Clay Mineralogy, and Geological Structures in the Formation of Large Landslide, a Case Study from Dumre Besei Landslide, Lesser Himalaya Nepal. Landslides, 10, 1-13. https://doi.org/10.1007/s10346-011-0311-7

[10] Vanmaercke, M., Ardizzone, F., Rossi, M. and Guzzetti, F. (2017) Exploring the Effects of Seismicity on Landslides and Catchment Sediment Yield: An Italian Case Study. Geomorphology, 278, 171-183. https://doi.org/10.1016/j.geomorph.2016.11.010

[11] Mallawaarachchi, R.S. and Jayasinghe, C. (2008) The Effects of Cyclones, Tsunami and Earthquakes on Built Environments and Strategies for Reduced Damage. Journal of National Science Foundation Sri Lanka, 36, 3-14. https://doi.org/10.4038/jnsfsr.v36i1.128

[12] Chen, C.W., Saito, H. and Oguchi, S. (2015) Rainfall Intensity-Duration Conditions for Mass Movement in Taiwan. Progress in Earth and Planetary Science, 2, 14. https://doi.org/10.1186/s40645-015-0049-2

[13] Tuhua, M., Lu, Z.M. and Changjiang Li. (2015) Rainfall Intensity-Duration Thresholds for the Initiation of Landslides in Zhejiang Province, China. Geomorphology, 245, 193-206.

[14] Caine, N. (1980) The Rainfall Intensity. Duration Control of Shallow Landslides and Debris Flows. Geografiska Annaler Series A, Physical Geography, 62, 23-27.

[15] Brunetti, M.T., Peruccacci, S., Rossi, M. and Luciani, S. (2010) Rainfall Thresholds for the Possible Occurrence of Landslides in Italy. Natural Hazards and Earth System Sciences, 10, 447-458. https://doi.org/10.5194/nhess-10-447-2010 
[16] Guzzetti, F. and Tonelli, G. (2004) Information System on Hydrological and Geomorphologic Catastrophes in Italy (SICI): A Tool for Managing Landslide and Flood Hazards. Natural Hazards and Earth System Science, 4, 213-232. https://doi.org/10.5194/nhess-4-213-2004

[17] Varnes, D.J. (1978) Slope Movement Types and Processes. In: Schuster, R.L. and Krizek, R.J., Eds., Landslide Analysis and Control, Special Report 176, Transportation Research Board, National Academy of Sciences, Washington DC, 12-33.

[18] Kanungo, D.P. and Sharma, S. (2014) Rainfall Thresholds for Prediction of Shallow Landslides around Chamoli-Joshimath Region, Garhwal Himalayas, India. Landslides, 11, 629-638. https://doi.org/10.1007/s10346-013-0438-9

[19] Nishikawa, T. and Balasooriya, R. (2016) Evaluation of Landslide Monitoring Data for Badulla Site in Sri Lanka. Proceedings of the 3rd International Symposium on Risk Awareness \& Future Challenges, Colombo, 1-3 September 2016, 65-73.

[20] Bandara, R.M.S. and Weerasinghe, K.M. (2013) Overview of Landslide Risk Reduction Studies. Landslide Science and Practice in Sri Lanka, 5, 345-352. https://doi.org/10.1007/978-3-642-31325-7_45

[21] Bandara, R.M.S. (2005) Landslides in Sri Lanka. Vidurava, 22, 9-13. http://dl.nsf.ac.lk/bitstream/handle/1/5564/VIDUE-22\%282\%29A-9.pdf?sequence= 1 \&isAllowed $=\mathrm{y}$

[22] Bandara, R.M.S. (2010) Overview and Advancement in Landslide Risk. SAARC Workshop on Landslide Risk Management in South Asia, 117-126.

[23] Karunathilaka, K., Dabare, H.K.V. and Nandalal, K.D.W. (2017) Changes in Rainfall in Sri Lanka during 1966-2015. Engineer the Institution of Engineers, Sri Lanka, 39-48. https://doi.org/10.4038/engineer.v50i2.7251

[24] Rathnaweera, T.D. (2012) Effects of Climate Change on Landslide Frequencies in Landslide Prone Districts in Sri Lanka; Overview. Civil Engineering Research Exchange Symposium, 112-117.

[25] DCS (Department of Census and Statistics-Sri Lanka) (2002) Agriculture and Environmental Statistic Division. Estate Sector Statistical Table No. 1 and Table No. 7. http://www.statistics.gov.lk/agriculture/

[26] DCS (Department of Census and Statistics-Sri Lanka) (2015) Spatial Distribution of Poverty in Sri Lanka.

[27] Karunanayake, M.M. (1988) An Environmental Profile of the Badulla District. Central Environmental Authority, Ministry of Environmental and Parliamentary Affairs, Sri Lanka, 12-13.

[28] B Cooray, P.G. (1994) The Precambrian of Sri Lanka: A Historical Review. Precambrian Research, 66, 3-18. https://doi.org/10.1016/0301-9268(94)90041-8

[29] Jayawardena, D.E.S. and Carswell, D.A. (1976) The Geochemistry of Charnockites and Their Constituent Minerals from the Precambrian of Southeast Sri Lanka. Mineralogical Magazine, 40, 541-554. https://doi.org/10.1180/minmag.1976.040.314.01

[30] Dissanayake, C.B. and Munasinghe, T. (1984) Reconstruction of the Precambrian Sedimentary Basin in the Granulite Belt of Sri Lanka. Chemical Geology, 47, 221-247. https://doi.org/10.1016/0009-2541(84)90127-X

[31] Ranjan, K.D. and Hasegawa, S. (2008) Representative Rainfall Thresholds for Landslides in the Nepal Himalaya. Geomorphology, 29, 429-443.

[32] Wijemannage, A.L., Ranagalage, M.M. and Perera, E.N.C. (2016) Comparison of Spatial Interpolation Methods for Rainfall Data over Sri Lanka. Asian Conference in Remote Sensing, Colombo. 
[33] Chang, C.W., Lin, P.S. and Tsai, C.L. (2016) Estimation of Sediment Volume of Debris Flow. Caused by Extreme Rainfall in Taiwan. Engineering Geology, 123, 83-90. https://doi.org/10.1016/j.enggeo.2011.07.004

[34] Dikshit, A. and Satyam, N. (2017) Rainfall Thresholds for the Prediction of Landslides using Empirical Methods in Kalimpong, Darjeeling, India. In: Workshop on Advances in Landslide Understanding, JTC1, Barcelona, 255-259.

[35] Keefer, D.K. and Wilson, R.C. (1987) Real-Time Landslide Warning during Heavy Rainfall. Science, 238, 921-925. https://doi.org/10.1126/science.238.4829.921

[36] Segoni, S., Battistini, A., Rossi, G., Rosi, A., Lagomarsino, D., Catani, F., Moretti, S. and Casagli, N. (2015) Technical Note: An Operational Landslide Early Warning System at Regional Scale Based on Space-Time Variable Rainfall Thresholds. Natural Hazards and Earth System Science, 15, 853-861.

https://doi.org/10.5194/nhess-15-853-2015

[37] Persichillo, M.G., Bordoni, M. and Meisina, C. (2016) The Role of Land Use Changes in the Distribution of Shallow Landslides. Science of the Total Environment, 574, 924-944. https://doi.org/10.1016/j.scitotenv.2016.09.125

[38] Abeysinghe, S. (2014) Climatic Variations in Tea Growing Regions and Vulnerability of Tea. Adaptation Stratergies for Climate Change and Carbon Friendly Tea Cultivation. The Tea Research Institute of Sri Lanka, Vol. 12, 1-8.

[39] Gostelow, T. (1980) Rainfall and Landlides. Engineering Geology Research Group, Notingham. 